\title{
Determinants of Individual Support for Independence: Evidence from Montenegro
}

\author{
Pëllumb Kelmendi ${ }^{1 *}$ (D) and Christian Pedraza ${ }^{2}$ \\ ${ }^{1}$ Auburn University, Auburn, Alabama, USA, and ${ }^{2}$ Emory University, Atlanta, Georgia, USA \\ ${ }^{\star}$ Corresponding author. Email: kelmendi@auburn.edu
}

\begin{abstract}
This article investigates the determinants of individual support for independence in Montenegro. We outline five theoretically distinct groups of factors covered by the literature and evaluate their impact on individual preference for independence. Using observational data obtained from a nationally representative survey conducted in Montenegro in 2003-2004, we find support for several hypotheses, showing that identity, income, and partisanship significantly impact individual opinion about independence. We also investigate and discuss the relative effect size of different factors associated with preference for independence. Additionally, we test variables with hitherto unexplored implications for opinions on independence, including the impact of support for EU membership, as well as support for democratic principles. Our logistic regression analyses reveal that attitudes towards EU integration and minority rights are strongly associated with support for independence. By systematically analyzing existing and new hypotheses with data from an understudied case, our findings contribute to the nascent literature on individual preferences for independence.
\end{abstract}

Keywords: Montenegro; secession; public opinion; national identity; ethnicity

\section{Introduction}

This article seeks to expand our understanding of the factors shaping individual preference for secession by systematically analyzing survey data from pre-independence Montenegro. Existing scholarly literature has paid significant attention to the determinants and trajectories of secessionist movements (Roeder 2018; Sambanis and Milanovic 2011), including in Montenegro (Bieber 2003; Džankić 2013; Huszka 2013; Morrison 2017; Macek-Macková 2011; Cross and Komnenich 2005). Studies about why independence campaigns arise and how they develop are important to understand individual secessionist attitudes and beliefs. The circumstances which encourage independence at the regional or group level strongly influence and may be parallel to those at work in the decision calculus of individuals to support independence once the claims have arisen. However, despite the valuable insights one can gain about the dynamics of secession by considering aggregate-level demands for sovereignty, it is also necessary to examine what influences an individual's opinion on independence.

Studies investigating demand for secession at the regional, group, or campaign levels of analysis cannot fully account for individual variation in preference for independence. To begin, support for secession varies within regions and groups. The actors that comprise an independence movement including elites, political parties, non-governmental organizations (NGOs), interest groups, and street-level community organizers - may themselves differ widely in their motivations and degree

\footnotetext{
(c) The Author(s), 2021. Published by Cambridge University Press on behalf of Association for the Study of Nationalities. This is an Open Access article, distributed under the terms of the Creative Commons Attribution licence (http://creativecommons.org/licenses/by/4.0/), which permits unrestricted re-use, distribution, and reproduction in any medium, provided the original work is properly cited.
} 
of support for independence. Importantly, they do not represent the full spectrum of attitudes and beliefs of the individuals who support independence. We therefore cannot assume that the arguments and justifications propagated by independence campaigns are fully or equally internalized across all of their supporters.

Furthermore, in many cases the support of the broader public is important for the success of an independence movement. In the specific context of independence referenda, individual attitudes towards independence are crucial for a successful vote in favor of secession. ${ }^{1}$ The bilateral agreement that allowed for the 2006 binding Montenegrin independence referendum stipulated that secession must be supported by at least 55 percent of the voters who participate. Indeed, the referendum barely passed with 55.53 percent support for independence, clearly indicating the importance of each voter in determining independence outcomes in referenda. For this reason, the study of more fine-grained factors which may affect an individual's support for independence is crucial to understanding the dynamics of independence movements, especially those which choose to conduct referenda on independence. Investigating the drivers of individual support, moreover, is also necessary in order to specify and refine the micro-foundations of aggregate-level theories of demand for sovereignty (Muñoz and Tormos 2015, 318).

This realization has given rise to a growing literature that focuses on the factors motivating individual attitudes towards secession. This academic literature has emphasized, in particular, the importance of identity (Serrano 2013), political partisanship and elite cues (Clarke et al. 2004), economic expectations (Muñoz and Tormos 2015), and international factors such as prospects for European Union (EU) membership (Muro and Vlaskamp 2016). With few notable exceptions (Sarigil and Karakoç 2016), however, this literature has focused primarily on multiethnic societies in consolidated democracies in the West. This is problematic because it cannot be assumed that the same factors shaping attitudes towards independence apply in different contexts.

To address this gap in the literature, we use survey data from pre-independence Montenegro to systematically analyze individual preferences for independence. Specifically, we explore data from a representative survey of the Montenegrin population, which was designed and implemented by the Institute for Sociology and Political Science at the Norwegian University of Science and Technology (Simkus, 2007) at the end of 2003 and the beginning of 2004. ${ }^{2}$ This survey provides us not only with a valid, reliable measure of support for independence in Montenegro at the time, but also with detailed information on various independent and control variables relevant to our theory. This fine-grained data enables us to test existing theories of determinants of individual support for secession in a new context. Indeed, to our knowledge, ours is the first study to use survey data to systematically analyze the factors shaping variation in individual-level support for independence in Montenegro.

Pre-independence Montenegro is an excellent case for studying the determinants of individual support for secession. Montenegro is one the newest countries to achieve independence following a referendum, and unlike other recent cases of successful independence referenda, such as those in South Sudan and East Timor, public opinion in Montenegro was much more divided on the issue of independence. This also distinguishes Montenegro of the early 2000s from other former Yugoslav republics that declared independence in the early 1990s, such as Croatia and Macedonia, where support for independence was overwhelming. In addition, Montenegro is an interesting case to study how international factors, particularly prospects of EU membership, influence support for secession. The literature on Catalonia and Scotland has already investigated concerns about how future EU membership shapes attitudes towards independence in regions that are already part of the EU (Muro and Vlaskamp, 2016). In Montenegro, on the other hand, prospects for future EU membership became entangled with debates over the merits of independence despite the fact that Serbia and Montenegro was not part of the EU at the time. Finally, careful examination of the Montenegro case allows us to inductively generate novel hypotheses about the determinants of individual-level variation in support for independence, such as propositions about the relationship between support for democracy and minority rights on the one hand and attitudes towards secessionism on the other. 
This article thus makes a two-pronged contribution to the literature. At the empirical level, we explore data from a representative survey of pre-independence Montenegro, an understudied case in the literature on individual-level determinants of support for independence. The survey data enable us to systematically test existing and novel hypotheses in a new context. Moreover, our quantitative analysis permits us to evaluate the relative effect size of different factors associated with support for independence, something that prior studies of public opinion in Montenegro have not done. At the theoretical level, the article contributes to a better understanding of individual-level attitudes towards independence by emphasizing the importance of understudied factors, such as support for EU membership or attitudes towards democracy and minority rights. Whereas qualitative studies of Montenegro's path to independence have consistently emphasized the importance of pro-democracy and minority rights rhetoric, the effect of attitudes towards democracy and minority rights on individual support for independence has not been investigated. To our knowledge, ours is the first study of individual-level determinants of support for independence to investigate this relationship.

The remainder of the article is organized in four sections. In the next section, we provide a brief historical overview of Montenegro's road to independence. The subsequent section presents existing theories of individual support for independence and derives testable hypotheses from these theories for the context of Montenegro. In this section, we also rely on existing studies of Montenegro to generate novel hypotheses hitherto unexplored by the broader literature on individual support for independence. In the last section we explain the research design, data sources, analyses, and results. A conclusion follows.

\section{Montenegro's Road to Independence: A Brief Historical Overview}

The issue of Montenegrin independence has deep historical roots (Rastoder 2003; Morrison 2017), and a detailed exposé of the processes that led to its independence, as well as the main actors involved, is outside the scope of this article. ${ }^{3}$ However, a brief historical overview is necessary in order to provide context for the discussion that follows.

It is important to note that debates over Montenegro's independence became salient during the breakup of the Socialist Federal Republic of Yugoslavia (SFRY). After four of SFRY's six republics declared independence, Montenegro and Serbia founded the Federal Republic of Yugoslavia (FRY) in 1992. Earlier that year, the vast majority of voters in Montenegro (95.4 percent) had supported the option of remaining within Yugoslavia, although this referendum was boycotted by some Montenegrin opposition parties as well as by the ethnic minorities in the republic. As Morrison (2017) notes, participation in the referendum was "only 66 percent if one takes into account the opposition boycott" (52). ${ }^{4}$ One of the main proponents of Montenegrin independence during this time was the Liberal Alliance of Montenegro (LSCG). Founded in Cetinje, the historical capital of Montenegro, LSCG criticized Montenegro's involvement in the war in Croatia in 1991, supported the re-establishment of the Montenegrin Orthodox Church, and drew upon Montenegro's independent past to appeal to a separate Montenegrin identity (Bieber 2003, 20). The ruling Democratic Party of Socialists (DPS), however, opposed secession, aligning itself with the regime of Serbia's Slobodan Milošević, while at the same time seeking to preserve Montenegro's equal status within the federation (Huszka 2013, 110). There were also parties that advocated for even closer ties between Serbia and Montenegro, such as the People's Party (NS), which emphasized Montenegro's Serbian identity and advocated for the unification of both republics (Bieber 2013, 124).

In the second half of the 1990s, however, increasing conflict between Milošević and Montenegro's Prime Minister, Milo Đukanović, strained relations between the two polities and eventually led the dominant DPS to embrace a pro-independence stance. Beginning in 1997, Đukanović and his faction within the DPS began blaming Serbia for Montenegro's economic challenges, criticizing Milošević for failing to normalize relations with the international community, international financial institutions in particular. Mass protests by opposition forces in Serbia during the winter 
of 1996-1997 also provided an impetus to break ties with Serbia, as Đukanović viewed the protests as an indicator of Milošević's weakness and used this opportunity to strengthen his position in Montenegro (Morrison 2017, 70). This led to a split within the DPS, with the party's president, Momir Bulatović, siding with Milosević and advocating for the status quo (Bieber 2003, 30-32). The power struggle between the DPS factions ended with Bulatović's removal from the party presidency and the subsequent formation of the Socialist People's Party (SNP) by the Bulatovic faction. In the 1997 presidential elections and the 1998 parliamentary elections, Đukanović would be accused by Bulatović of corruption and secessionism, although at that time Đukanović campaigned only on a platform of economic and political reforms, which included a higher degree of autonomous decision-making in Montenegro and closer ties with the West, but not outright independence (Huszka 2013, 110; Bieber 2003, 31).

Đukanović's victory in the 1997 and 1998 elections was followed by a constitutional stand-off with Serbia over representation in the federal parliament and the eventual exclusion of Montenegro's government from federal decision-making by Milošević. In June 2000, for example, the FRY government adopted several amendments to the constitution that were aimed at diminishing the power of Montenegro in the federation, the most controversial of which introduced direct elections of the president. Following this, the ruling coalition in Montenegro declared that they would boycott the September 2000 elections. Moreover, Montenegro ceased to recognize federal legislation, and by 2000 the two republics were operating as separate economic zones (Morrison 2017, 100-101). It was during this time that "the idea of independence and the theme of statehood entered the DPS's discourse" (Huszka 2013, 117). The 1998-1999 war in Kosovo also played a role in deepening the wedge between Montenegro and Serbia. NATO military intervention in the conflict, and the loss of the war by Serbia, validated the DPS's strategy to maintain a neutral stance in the conflict (Morrison 2017, 95) and further strengthened resolve to pursue independence (Bieber 2003, 34).

Although the Montenegrin government had been arguing that lack of democracy in Serbia was impeding Montenegro's political and economic development, the fall of Miloševićs regime in October 2000 did not end its push for independence (Morrison 2017, 103). In fact, by that time, Montenegro had already assumed many functions of an independent state, and public opinion polls showed increased support for independence (Bieber 2003, 34). In the 2001 early parliamentary elections, a coalition of pro-independence parties led by the DPS achieved a narrow victory and Montenegro's President Djukanović began promoting the idea of a "velvet divorce" to dissolve FRY (Darmanović 2003, 151). This proposal was initially resisted by the international community, especially by the foreign policy establishments in the EU and the US, who feared that Montenegro's independence would have a destabilizing effect on the region (ICG 2006, 2). Instead, with the help of EU mediation, Montenegro and Serbia signed the Belgrade Agreement on March 14, 2002, which paved the way for the creation of the State Union of Serbia and Montenegro in 2003, a loose confederacy with a largely symbolic president and parliament. However, upon the insistence of the Montenegrin side, the agreement included an opt-out clause that permitted either Montenegro or Serbia to begin independence procedures within three years of the creation of the new state (ICG 2006, 2).

The State Union of Serbia and Montenegro replaced the dysfunctional federal Yugoslav structures with a nominal central government, including a parliament composed of delegates from both states but lacking any real authority and unpopular in both Montenegro and Serbia (ICG 2006, $1-2)$. The indirectly elected council of ministers included only five members, and was led by a chairman, not a prime minister. The assassination of the Serbian prime minister, Zoran Djindjić, shortly after the state union was established, emboldened the pro-independence voices in Montenegro who had been arguing that Serbia was not yet ready to democratize (Morrison 2017, 111). Delays in the EU accession process due to Serbia's lack of cooperation with the Hague Tribunal also continued to frustrate Montenegro's government (Huszka 2013, 135). By mid-2004 the EU members adopted a "twin-track" policy of negotiating EU integration, which further weakened 
the State Union (Kim 2006, 3-4). As Huszka (2013) notes “the double-track model by the EU during the accession and stabilization process also indicated that the integration process via the common state model was not working" (138). Furthermore, elections for the State Union's parliament were never organized and the two republics began chartering very different economic development paths. Meanwhile, the Montenegrin government continued its nation building policies, adopting new state symbols, altering the national anthem, erecting new monuments, and changing the official language from Serbian to Maternji jezik (mother tongue) (Džankić 2014; Morrison 2017, 112-114). As the referendum became increasingly likely, unionist political parties and organizations joined forces to establish a coalition for the preservation of the State Union. A counterpart pro-independence coalition was subsequently formed in 2005 (Morrison 2017, 116-118).

The referendum campaign would be vigorously but peacefully contested by both sides. As ICG (2006, 3-6) notes, the unionist bloc primarily targeted the majority Eastern Orthodox Slavs, and its campaign rhetoric was occasionally reminiscent of the Serbian ethnonationalism of the 1990s. In addition, the unionists emphasized government corruption and drew on fears related to the economic and financial repercussions of ending ties with Serbia. The pro-independence campaign, on the other hand, targeted Montenegrin loyalists, youth, and the national minorities. It argued that Montenegro could join the EU faster if it were not held back by Serbia and emphasized that an independent Montenegro would be "a civic state based on civic values that included many nationalities" (ibid., 5). The second referendum in Montenegro was held in May 2006, with 86.49 percent turnout and 55.53 percent of voters favoring independence. The following month, the new state of Montenegro joined the United Nations.

The narrow result of the second referendum demonstrated the deep and longstanding divisions over the issue of independence within Montenegrin society and its political elite. In addition to identity politics, the debate over Montenegro's status was informed by a complex set of interconnected factors, including party politics, concerns about political and economic development, and international political considerations. In her in-depth analysis of the discursive construction of the Montenegrin independence movement, Huszka (2013) argues that the overarching claim of the Montenegrin independence movement was "that independence was a condition for democratic and economic development and faster accession to the EU” (104). Importantly, the pro-independence forces promoted an inclusive national identity, arguing for the inclusion of non-Orthodox ethnic minorities, including Albanians and Bosniaks. In contrast, the unionist forces "drew on an ethnonationalist discourse hostile to minorities" and sought to undermine the pro-independence parties by accusing them of corruption and organized crime (Huszka 2013, 105).

Public opinion polls throughout this period confirm the societal division over the issue of independence. As already noted, in 199295.4 percent had voted for staying in FRY, although the referendum was boycotted by LSCG and ethnic minorities. Even in 1997, over 65 percent of the society still supported a joint state (Huszka 2013, 117). Only after the war in Kosovo, in September 1999, would polls record a narrow majority support for Montenegrin independence (Bieber 2003, 34). By 2001 this support increased to 49.8 percent (ICG 2001, 12), after which it declined somewhat with polls usually indicating a small lead for the pro-independence side, but not with an absolute majority (ICG 2006, 2). Between 2003 and 2006, public opinion polls conducted by the Centre for Democracy and Human Rights (CEDEM) showed support for independence hovering between 39.2 percent and 44.5 percent, until April 2006 when support for independence rose to 49 percent (CEDEM 2006, 123). The proportion of survey respondents who opposed independence during this time period, on the other hand, ranged from a low of 32.1 percent to a high of 39.1 ; the share of those who declared that they would abstain ranged from 15 percent to 32.3 percent (CEDEM 2006, 123).

\section{Literature Review and Hypotheses}

To structure our consideration of the determinants of attitudes towards independence in Montenegro, we outline five groups of factors covered by the literature and evaluate their impact: group 
identity, economic expectations, partisanship and elite cues, international factors, and concerns about democratic governance. Our intention is to not only test these hypotheses in the context of Montenegro, but to also determine the relative strength and importance of each of the factors highlighted in the literature in predicting individual-level support for independence in Montenegro. It is important to emphasize specifically how individual determinants are different from grouplevel indicators of support for secession. In their assessment of individual attitudes towards Kurdish autonomy in Turkey, Sarigil and Karakoç (2016) argue that, compared to group level indicators such as vote share for ethnonationalist parties, "individuals' opinions and attitudes toward the idea of separation or autonomy would provide a more direct and precise measurement of mass support for secession" (333). Despite the inferences one can draw from mass support for a political outcome such as independence, societal groups are often not monolithic, and it is thus important to understand preferences for independence at a granular level, especially in the context of a social and institutional transformation as complete as secession.

Numerous studies of individual preferences for sovereignty have shown a strong association between identity and support for independence (Howe 1998; Serrano 2013; Muñoz and Tormos 2015; Costa i Font and Tremosa i Balcells 2006). These studies have proposed several different mechanisms connecting identity to demand for sovereignty. First, identity may shape individual perceptions of the costs and benefits associated with secession. In his study of secessionist attitudes in Quebec, for example, Howe $(1998,40)$ argues that the stronger an individual's Québécois identity, the more likely they are to consider that the French language in Quebec is being endangered and that their standard of living in an independent Quebec would improve. ${ }^{5}$ Others have emphasized the way in which psychological attachment to a particular identity shapes individual views about political reality. According to this line of thought, identity serves as an important source of orientation for an individual's political attitudes, especially attitudes towards independence (Blais and Nadeau 1992, 95). Costa i Font and Tremosa i Balcells (2006) similarly emphasize the "non-monetary payoffs" and "symbolic utility" associated with acting in accordance with identity, arguing that "identity operates in such a way that it fosters individuals' preferences to favor certain behaviors that, if violated, would cause psychological costs or frustration with their perceived self" $(3-7){ }^{6}$

However, when it comes to ethnic identification, it is not always as simple as identifying solely with one group and not with another. When regions have existed for decades under the rule of a parent state dominated by a national ethnic group, it is possible for dual identities to arise among ethnic minorities; in essence, citizens may consider themselves both members of their ethnic group and citizens of their country, each to varying degrees. Serrano (2013), for example, examines how dual identity affects Catalonian citizens to support independence, finding that those who possess some level of a dual identity are more likely to support increased decentralization in Catalonia than those who identify solely as Spanish. He argues that in multiethnic states like Spain, citizens of Catalonia who identify as Catalan are influenced in their opinions by both Spain, who prefers to remain in union, and Catalonia, who prefers secession; conversely, Spaniards in Catalonia who speak Spanish are only influenced by Spain, as they have no additional connection to Catalonia based solely on ethnic identity.

In the case of Montenegro, throughout the 1990s and early 2000s, public opinion on independence corresponded with debates over the nature of Montenegrin identity (Džankić 2013; Džankić 2014; Bieber 2003, 11; ICG 2006, 4). Montenegrins and Serbs, Montenegro's majority population who identify as Eastern Orthodox Slav, share the same language and religion, and "the boundaries between Serbian and Montenegrin identity are rather fluid" (Huszka 2003, 43). ${ }^{7}$ During the late 1990s and early 2000s, however, national and ethnic identification of this population became increasingly entangled with debates over Montenegro's relationship with Serbia, in large part due to the politicization of historical narratives and the reinforcement of other overlapping cleavages in Montenegrin society (Džankić 2013). Thus, by the time of the referendum, there were two nationalisms among majority Eastern Orthodox Slav population in Montenegro: Serbian 
nationalism, which had been especially potent in the early 1990s, and Montenegrin nationalism, whose proponents linked Montenegrin identity with the history of Montenegro as an independent entity and the myth of interethnic coexistence (Bieber 2003, 42). ${ }^{8}$

On the other hand, non-Eastern Orthodox minorities in Montenegro - especially Albanians, Croats, and Bosniaks-Muslims - were largely in favor of independence. During the wars in Bosnia and Herzegovina, Croatia, and Kosovo, these minorities had become a target of Serb nationalist propaganda and experienced intimidation and violence by members of Serb paramilitary forces (Šístek and Dimitrovová 2003, 159-179). Moreover, whereas the pro-independence forces welcomed minority participation, the unionist supporters attacked and demonized minorities, portraying them as a threat to Montenegro's territorial integrity (ibid., 178). As ICG (2006) notes, unionist "campaign rhetoric was reminiscent of the 1990s, including hate speech attacking Islam, Albanians, and Croats, in the hope this would motivate Orthodox Slavs to vote against independence" (4). Therefore, in order to test the impact of identity on support for independence, we derive the following hypotheses.

Hypothesis 1a: Those who self-identify as Montenegrin will be more likely to support independence than those who self-identify as Serbs.

Hypothesis 1b: Those who self-identify with minority ethnic groups in Montenegro will be more likely to support independence than those who self-identify as Serbs.

The literature also emphasizes the role of partisanship and elite cues in shaping individual demand for secession. Among others, citizens rely on elite and party cues to evaluate the cost and benefits of secession, which is both a high-stakes and highly uncertain option (Muñoz and Tormos 2015, 319). Indeed, identification with specific parties and leaders has been shown consistently to have a possible independent effect on opinions regarding sovereignty (Clarke et al. 2004; see also Clarke and Kornberg 1996; Pammett and LeDuc 2001). In the case of Catalonia, Torcal and Mota (2014) demonstrate the importance of political party effects for the formation of citizens' preferences, showing that regional nationalist parties positively predict support for decentralization, taking into account national identity and various aspects of the party system. Importantly, parties that have an opinion on independence are not monoliths. Political parties which are unified on the subject of independence, as opposed to those which are internally fragmented, are more likely to sway the opinions of their followers (Steenbergen et al. 2007).

As applied to the case of Montenegro, we consider the relationship between a person's party identification and their views on independence. As already noted, from 1998 onwards the parties pushing for independence included LSCG, DPS, and SDP, as well as the parties of ethnic minorities such as Albanians and Bosniaks. Parties that formed the principal opposition to Đukanović's government favored closer links with Serbia. These included not only the People's Party (NS) and the Serbian People's Party (SNS), but also the Socialist People's Party (SNP) which was led by former DPS leader Momir Bulatović (Bieber 2013). We thus propose the following hypotheses:

Hypothesis 2a: Those citizens who are supporters of pro-independence parties will be more likely to support independence than citizens with no party preference.

Hypothesis 2b: Those citizens who are supporters of unionist parties will be less likely to support independence than citizens with no party preference.

Previous scholarship has also posited that citizens concern themselves with the potential economic viability of the breakaway region post-independence and take it into account when deciding to support independence (Muñoz and Tormos 2015; Liñeira, Henderson, and Delaney 2017; Nadeau, Martin, and Blais 1999). In the wake of the 1995 Quebecois independence referendum, former Canadian Foreign Minister Stéphane Dion argued that confidence about economic success after independence works in tandem with fear associated with remaining in union with the parent state to determine citizens' preferences for independence (Dion 1996). Gehring and 
Schneider (2020) lend empirical evidence to this claim with their recent finding that relative regional wealth positively impacts support for secessionist parties in Scotland and Wales; they argue that regions with higher endowed wealth from natural resources are more confident in their ability to prosper as an independent state, and are thus more likely to demand sovereignty.

At the individual level, factors of economic viability are more directly observed when considering the effect of socioeconomic status on support for independence, although existing empirical evidence about the relationship between socio-economic status and secessionist demands is mixed. In what is known as the modernization approach, higher socioeconomic status is believed to lead to lower support for independence (Horowitz 1981, 170), implying that upward social mobility and higher education weaken ethnic identification and demand for secessionism (Sarigil and Karakoç 2016, 329). According to this line of thought, those with lower incomes may be more likely to support independence due to increased fear of remaining in union with a state that does not realize their best economic interests. However, the modernization approach is disputed, as several scholars have pointed out instances of wealthy ethnic groups seeking independence (Wood 1981) or separatist movements specifically targeting poorer, working-class individuals, who are decidedly less educated (Hayes and McAllister 2001; O'Gara 2001). According to this other strand of literature, secession may actually create a larger amount of uncertainty for those who are already experiencing higher amounts of economic insecurity, making them less likely to support a drastic shift in political order.

Conversely, those who are wealthier may feel less concerned about what independence would do to their financial status, and thus may be more likely to support independence than those with lower incomes. Greater access to resources may allow those with higher incomes to adapt more easily to changing circumstances, thus increasing their confidence in their chances of continued success post-secession (Dion 1996). Indeed, Montenegro scholars and observers have argued that "the more educated and wealthier strata have generally been more optimistic regarding the consequences of separation from Serbia" (Huszka 2003, 47). We thus test these competing hypotheses regarding socio-economic status and support for independence, predicting that those with higher socioeconomic status are more likely to support secession in Montenegro.

Hypothesis 3: Citizens with higher socio-economic status (specifically higher levels of income and education) will be more likely to support independence.

We also consider the relationship between an individual's opinion on international and supranational organizations and their support for independence. Major power recognition and membership in international organizations is one method of lending legitimacy to seceding states (Caspersen 2011; Coggins 2011; Tesser 2019), and therefore is often a goal of newly sovereign entities. However, membership in supranational organizations such as the EU is rarely without domestic political implications; in other words, there are some who believe that international organizations are beneficial to the success of their country and there are those who view such organizations as entangling and restrictive of its members, and these two groups may also disagree on a range of political issues (Schumacher 2019). Muro and Vlaskamp (2016) employed an original survey experiment that varied informational treatments about the degree of difficulty of accession to the EU post-secession, finding that better prospects of joining the EU led to an increase in support for independence in Catalonia and Scotland. Crucially, those with less trust in the EU as an institution were less affected by indications of greater likelihood of joining the EU, suggesting the impact of opinions regarding the EU may themselves have a direct impact on independence.

Unlike both Spain and the United Kingdom, Serbia and Montenegro was never a member of the EU. However, there was widespread popular support for joining the EU. Survey respondents in the early 2000s identified EU membership with a myriad of economic benefits, including higher salaries, the ability to travel freely, access to a larger market, access to European investment, and the adoption of European standards (NDI 2004, 18). EU integration, moreover, was supported by the majority of both pro-independence party supporters and pro-Serb party supporters, although a 
larger percentage of pro-independence party supporters desired EU membership (CEDEM 2004, 32). Furthermore, as already noted, the pro-independence elites in Montenegro more heavily emphasized EU integration, arguing that "Montenegro could move towards Brussels faster if it was not harnessed to Serbia" (ICG 2006, 5). More specifically, according to independence advocates, Montenegro would have an easier time implementing the reforms and fulfilling the conditions required to join the EU. These conditions included, first and foremost, the extradition of war criminals. Although by the mid-2000s Serbia and Montenegro had been promised an accelerated EU accession process, the "process hit repeated delays due to Serbia's failure to cooperate on issues such as the International Criminal Tribunal for the Former Yugoslavia (ICTY)" (ICG 2006, 2). Furthermore, the reforms and benefits associated with the EU accession process, such as deeper democratization, minority rights, combating the shadow economy, and international aid, were similarly tied to the independence agenda (ICG 2006; Huszka 2013; Morrison 2017). In contrast, as Huszka $(2013,124)$ notes, the "ideals promoted by the EU were in sharp contrast with xenophobic ethnic nationalism" associated with the base of unionist forces. Therefore, in general, unionist voters and those who defined themselves as Serbs were perceived of as being "less enthusiastic about joining the EU" (ICG 2006, 4). We thus produce the following hypothesis:

Hypothesis 4: Those who are more favorable towards European Union membership are more likely to support Montenegrin independence.

Finally, we investigate the association between support for democratic principles and secessionist attitudes. Although the literature on individual-level determinants has not explored this relationship, as noted earlier, a key theme within the pro-independence camp in Montenegro was the idea that an independent Montenegro would be more strongly committed to democratic principles, constitutionalism, and human rights. In her study of debate-framing and rhetoric in the Montenegrin independence campaign, Huszka (2013) argues that the pro-independence forces discursively linked the independence agenda to democratic ideals. In particular, she underscores two key themes within this "democracy frame:" an emphasis on democratic reforms and democratization as well as a civic concept of society based on human rights and minority rights.

Given this emphasis on democratic principles by the pro-independence campaign, attitudes towards democracy and authoritarianism may be helpful in suggesting motives for individual support for independence both in Montenegro and elsewhere. For example, those who are more supportive of democratic governance may support independence as a means of escaping what they consider an overly authoritarian regime in the hope of building a more liberal state. Alternatively, perhaps the idea of secession evokes feelings of betrayal for those who are more loyal to the regime and more accepting of a strong central government, leading to opposition. At the core of this analysis is an examination of the concept of liberal democratic norms-how individuals interact with norms of liberalism in daily civic life, and how they respond when those norms are challenged by the prospect of secession. We thus develop the following hypotheses regarding the effect of democratic norms and beliefs on attitudes towards independence in Montenegro.

Hypothesis 5a: Those citizens who support democratic consolidation are more likely to support independence.

Hypothesis 5b: Those citizens who support human and minority rights are more likely to support independence.

\section{Empirical Test}

In this section, we use logistic regression analyses to test the hypotheses outlined above. The individual-level data stems from the South-East European Social Survey Project (SEESSP), a crosscountry survey conducted in late 2003 and early 2004 by the Institute for Sociology and Political Science at the Norwegian University of Science and Technology (Simkus 2007). SEESSP surveyed 
23,000 respondents in seven Western Balkan countries with face-to-face interviews that lasted on average around 75 minutes. The nationally representative sample for Montenegro, including special samples for ethnic minorities, incorporated a total of 1,849 respondents above the age of 17 years. ${ }^{9}$

The SEESSP survey fielded in Montenegro included a question on attitudes toward independence which we use to code support for independence, our dependent variable. The question was phrased as follows: "In recent years, the public can often hear different views on the issue of Montenegro's independence, that is its common life with Serbia. What is your attitude towards this issue?" The answer categories were (1) "I am a supporter of state independence for Montenegro," (2) "I support a common state of Serbia and Montenegro," (3) "It is all the same to me if Montenegro will be independent [or not]," (4) "Does not know," and (5) "Refuses to answer." We created a dummy variable that takes on a value of 1 if an individual declared that they support Montenegro's independence, and 0 otherwise. Those who refused to answer were treated as missing data and removed from the main analysis.

Our main independent variables are ethnic identity, political party preferences, support for EU integration, socio-economic status, and attitudes toward democratic values. In line with previous work that has employed the SEESSP data (Dyrstad 2012), ethnic identity is measured as a set of dummy variables based on the individual's self-assessment of the ethnic group or nationality to which they primarily belong. ${ }^{10}$ The survey had numerous answer categories of ethnic identity, including Montenegrin, Serb, Montenegrin-Serb, Serbian-Montenegrin, Albanian, Bosniak, and Other. We use Montenegrin as the reference category. ${ }^{11}$ In addition, we have recoded several small minorities into a common Other category. ${ }^{12}$ Finally, those whose answer to the question on nationality was "Mixed-cannot describe," "Don't know," or "Refused to answer" were treated as missing data (5.35 percent of respondents). Table 1 shows the distribution of the responses for the entire Montenegro population about preferences for the status of Montenegro, grouped by ethnic identification.

Results in Table 1 indicate a narrow plurality in favor of union with Serbia: 36.6 percent of the survey respondents declared that they supported a common state of Serbia and Montenegro whereas 33.3 percent declared support for Montenegrin independence. Those who declared that it is all the same to them if Montenegro will be independent or not constituted 14.7 percent of respondents. Seven percent of respondents declared that they did not know, and 8.4 percent refused to answer. Although publicly available data on support for independence in Montenegro in 2003

Table 1. Distribution of Preferences for the Status of Montenegro (SEESSP Survey, 2003-2004)

\begin{tabular}{|c|c|c|c|c|c|c|c|}
\hline Response Category & Montenegro & Montenegrin & Serb & $\begin{array}{l}\text { Montenegrin- } \\
\text { Serb }\end{array}$ & Albanian & Bosniak & Other \\
\hline $\begin{array}{l}\text { I am a supporter of state } \\
\text { independence for } \\
\text { Montenegro }\end{array}$ & 33.30 & 47.49 & 2.96 & 7.69 & 79.71 & 57.77 & 26.67 \\
\hline $\begin{array}{l}\text { I support a common state } \\
\text { of Serbia and } \\
\text { Montenegro }\end{array}$ & 36.57 & 19.39 & 78.57 & 53.85 & 2.00 & 7.43 & 30.67 \\
\hline $\begin{array}{l}\text { It is all the same to me if } \\
\text { Montenegro will be } \\
\text { independent }\end{array}$ & 14.67 & 17.92 & 7.39 & 18.46 & 10.86 & 19.59 & 24.00 \\
\hline Does not know & 6.98 & 6.27 & 4.68 & 12.31 & 4.86 & 9.80 & 8.00 \\
\hline Refuses to answer & 8.36 & 8.78 & 6.4 & 7.69 & 2.57 & 5.41 & 10.67 \\
\hline Observations & 1449 & 558 & 406 & 65 & 350 & 296 & 75 \\
\hline
\end{tabular}

Note: Percent of respondents declaring preference for each response category. Estimations for Montenegro-wide population are made using a population weight. 
and 2004 are difficult to find, the few available surveys on the topic from this period revealed similar results. A public opinion survey conducted in April 2004 by CEDEM, for example, found that 39.8 percent of respondents were in favor of independence whereas 39.7 percent were against, and 20.5 percent did not know (CEDEM 2004). ${ }^{13}$

As expected, we observe a significant difference in preference for independence depending on ethnic self-identification. Only 2.96 percent of Serb respondents favor independence, whereas 78.57 percent support a common state. Interestingly, those who self-identify as Montenegrin are rather split on the issue. A majority (47.49 percent) favor independence, but almost 20 percent support a common state, with a significant number declaring that it is all the same to them (17.92 percent). This indicates that self-identification with Montenegrin identity does not entirely overlap with support for independence. On the other hand, an overwhelming 80 percent of Albanian respondents support independence, followed by 58 percent of Bosniaks.

We also include party preference as an independent variable. In the survey, party preference is measured with a standard question that invites the respondent to answer what party s/he prefers most. We create a set of dummy variables for each party, using as a reference category those respondents who did not declare a party preference. ${ }^{14}$ Hypothesis 4 expects attitudes towards the $\mathrm{EU}$ to be associated with preferences for independence in Montenegro. In the survey, respondents were asked whether they agree with the statement that Montenegro should join the EU. Thus, preference for EU integration is entered as an ordinal variable (on a 1-5 scale), following the coding in the SEESSP survey. ${ }^{15}$

We further test for an association between support for democratic principles and preference for independence. Unfortunately, the survey did not include any questions that directly gauge respondent support for democracy or their evaluation of democracy as a form of government (see Dyrstad 2013, 1225). However, we create two proxy variables that we believe capture people's liberal democratic principles. The first variable, support for independent media, is an ordinal variable that measures the extent to which respondents agree or disagree with the statement that an independent media is necessary for the development of democracy. ${ }^{16}$ The second variable, support for minority rights, is a dummy variable that takes the value of 1 if respondents support the idea that minorities should have the right to schools in their own language, and 0 if they do not. ${ }^{17}$

The survey questionnaire did not include a question on respondent expectations about the economic prospects of an independent Montenegro. Instead, we used income and education levels to investigate the impact of socio-economic status on preferences for independence more broadly. Education was measured as the total number of years of full-time formal education completed by the respondent. ${ }^{18}$ In order to account for the relative economic position of each respondent within Montenegro, we follow Eikemo and Ringdal (2016) in measuring household income "by annual household income adjusted for household size, divided into three equal size groups for each country, plus an extra category for those without reported income" (71). ${ }^{19}$

While investigating the relationship between the aforementioned variables and support for independence, we also control for the impact of several other potentially relevant variables, including sex, age, unemployment, urban residence, and region. ${ }^{20}$ For example, observers of Montenegro have noted that divisions over the issue of independence were also geographic in nature (ICG 2001, 15). Montenegro is commonly divided into three regions - Coastal (Southern), Central, and Northern - which are characterized by important socio-economic differences (Radović et al. 2006). Opposition to independence was generally stronger in certain areas of the Northern region, in part due to its proximity with Serbia (ICG 2001, 15), whereas pro-independence parties usually performed better in the Coastal region and the historical heartland of the Central region (Bieber 2003 39-40). ${ }^{21}$ Table 2 below provides the descriptive statistics for all of the relevant variables measured in the SEESSP survey.

In Table 3 below we show the results of the main logistic regression analyses for our dependent variable of support for independence. All models in the table control for age, sex, employment status, residence, and region. The first model considers ethnic identity and socioeconomic variables. 
Table 2. Descriptive Statistics

\begin{tabular}{|c|c|c|c|c|c|}
\hline Variable Name & $N$ & $M$ & $S D$ & Min & $\operatorname{Max}$ \\
\hline Support for Independence & 1705 & 0.453 & 0.498 & 0 & 1 \\
\hline Education & 1754 & 11.333 & 3.227 & 0 & 24 \\
\hline No Income & 1704 & 0.038 & 0.19 & 0 & 1 \\
\hline Low Income & 1694 & 0.34 & 0.47 & 0 & 1 \\
\hline Medium Income & 1694 & 0.31 & 0.46 & 0 & 1 \\
\hline High Income & 1694 & 0.32 & 0.46 & 0 & 1 \\
\hline Montenegrin & 1750 & 0.319 & 0.466 & 0 & 1 \\
\hline Serb & 1750 & 0.232 & 0.422 & 0 & 1 \\
\hline Montenegrin-Serb & 1750 & 0.037 & 0.189 & 0 & 1 \\
\hline Albanian & 1750 & 0.2 & 0.4 & 0 & 1 \\
\hline Bosniak & 1750 & 0.169 & 0.375 & 0 & 1 \\
\hline Other Ethnicity & 1750 & 0.043 & 0.203 & 0 & 1 \\
\hline DPS (Democratic Party of Socialists) & 1602 & 0.207 & 0.405 & 0 & 1 \\
\hline SNP (Socialist People's Party) & 1602 & 0.034 & 0.182 & 0 & 1 \\
\hline NS (People's Party) & 1602 & 0.009 & 0.093 & 0 & 1 \\
\hline SNS (Serb People's Party) & 1602 & 0.013 & 0.114 & 0 & 1 \\
\hline LSCG (Liberal Alliance) & 1602 & 0.034 & 0.182 & 0 & 1 \\
\hline SDP (Social Democratic Party) & 1602 & 0.023 & 0.15 & 0 & 1 \\
\hline DSA (Albanian Democratic Alliance) & 1602 & 0.026 & 0.16 & 0 & 1 \\
\hline DUA (Albanian Democratic Union) & 1602 & 0.062 & 0.241 & 0 & 1 \\
\hline SRS (Serbian Radical Party) & 1602 & 0.009 & 0.096 & 0 & 1 \\
\hline Other Party & 1602 & 0.021 & 0.142 & 0 & 1 \\
\hline No Party Preference & 1602 & 0.561 & 0.496 & 0 & 1 \\
\hline Support for Ind. Media & 1701 & 4.194 & 0.764 & 1 & 5 \\
\hline Support for Minority Rights & 1670 & 0.741 & 0.438 & 0 & 1 \\
\hline Pro EU & 1045 & 4.315 & 0.764 & 1 & 5 \\
\hline Sex & 1849 & 0.49 & 0.5 & 0 & 1 \\
\hline Age & 1849 & 43.8 & 16.2 & 17 & 90 \\
\hline Unemployed & 1844 & 0.256 & 0.436 & 0 & 1 \\
\hline Urban & 1848 & 0.634 & 0.482 & 0 & 1 \\
\hline Northern Region & 1499 & 0.38 & 0.486 & 0 & 1 \\
\hline Central Region & 1499 & 0.39 & 0.49 & 0 & 1 \\
\hline Coastal Region & 1499 & 0.22 & 0.414 & 0 & 1 \\
\hline
\end{tabular}


Table 3. Logit Estimation Results for Support for Independence (2003-2004)

\begin{tabular}{|c|c|c|c|c|c|c|c|c|}
\hline \multirow{2}{*}{$\begin{array}{l}\text { Variables } \\
\text { Education }\end{array}$} & \multicolumn{2}{|l|}{ M1 } & \multicolumn{2}{|c|}{ M2 } & \multicolumn{2}{|c|}{ M3 } & \multicolumn{2}{|c|}{ M4 } \\
\hline & $0.054^{\star}$ & $(0.028)$ & 0.029 & $(0.032)$ & -0.010 & $(0.035)$ & -0.036 & $(0.055)$ \\
\hline $\begin{array}{l}\text { No Income (ref. } \\
\text { High Income) }\end{array}$ & -0.053 & $(0.420)$ & -0.220 & $(0.448)$ & -0.104 & $(0.518)$ & -0.044 & $(0.775)$ \\
\hline Low Income & $-0.690^{\star \star \star}$ & $(0.222)$ & $-0.882^{\star \star \star}$ & $(0.247)$ & $-0.798^{\star \star \star}$ & $(0.273)$ & $-0.891^{\star \star}$ & $(0.421)$ \\
\hline Medium Income & $-0.508^{\star \star}$ & $(0.202)$ & $-0.533^{\star \star}$ & $(0.227)$ & -0.400 & $(0.249)$ & -0.158 & $(0.369)$ \\
\hline $\begin{array}{l}\text { Serb (ref. } \\
\quad \text { Montenegrin) }\end{array}$ & $-3.523^{\star \star \star}$ & $(0.343)$ & $-3.090^{\star \star \star}$ & $(0.394)$ & $-3.140^{\star \star \star}$ & $(0.425)$ & $-3.730^{\star \star \star}$ & $(0.767)$ \\
\hline Albanian & $1.651^{\star \star \star}$ & $(0.322)$ & $1.192^{\star \star \star}$ & $(0.402)$ & $0.763^{\star}$ & $(0.410)$ & -0.304 & $(0.574)$ \\
\hline Bosniak & $0.451^{\star}$ & $(0.248)$ & 0.247 & $(0.269)$ & 0.066 & $(0.304)$ & 0.083 & $(0.481)$ \\
\hline Montenegrin-Serb & $-2.667^{\star \star \star}$ & $(0.485)$ & $-2.145^{\star \star \star}$ & $(0.473)$ & $-2.447^{\star \star \star}$ & $(0.510)$ & $-2.869^{\star \star \star}$ & $(0.995)$ \\
\hline Other Ethnicity & $-0.977^{\star \star \star}$ & $(0.323)$ & $-0.815^{\star \star}$ & $(0.393)$ & $-0.992^{\star \star}$ & $(0.430)$ & -0.501 & $(0.756)$ \\
\hline $\begin{array}{l}\text { DPS (ref. no party } \\
\text { preference) }\end{array}$ & & & $1.474^{\star \star \star}$ & $(0.206)$ & $1.416^{\star \star \star}$ & $(0.232)$ & $1.342^{\star \star \star}$ & $(0.350)$ \\
\hline SNP & & & -0.252 & $(0.701)$ & -0.311 & $(0.728)$ & -0.473 & $(1.415)$ \\
\hline LSCG & & & $1.725^{\star \star \star}$ & $(0.434)$ & $1.613^{\star \star \star}$ & $(0.472)$ & $1.884^{\star \star}$ & $(0.783)$ \\
\hline SDP & & & $2.333^{\star \star *}$ & $(0.667)$ & $2.148^{\star \star \star}$ & $(0.653)$ & 1.488 & $(1.125)$ \\
\hline DSA & & & $2.668^{\star \star \star *}$ & $(0.803)$ & $2.759^{\star \star \star \star}$ & $(0.807)$ & $2.225^{\star \star}$ & $(1.106)$ \\
\hline DUA & & & 0.828 & $(0.950)$ & 0.715 & $(0.899)$ & 0.101 & $(1.302)$ \\
\hline Other Party & & & 0.483 & $(0.415)$ & 0.239 & $(0.437)$ & 0.612 & $(0.649)$ \\
\hline $\begin{array}{l}\text { Support for } \\
\text { Independent } \\
\text { Media }\end{array}$ & & & & & -0.024 & $(0.137)$ & -0.300 & $(0.234)$ \\
\hline $\begin{array}{l}\text { Support for } \\
\text { Minority Rights }\end{array}$ & & & & & $0.424^{\star}$ & $(0.234)$ & 0.546 & $(0.367)$ \\
\hline EU Support & & & & & & & $0.583^{\star \star}$ & $(0.288)$ \\
\hline Sex & $-0.681^{\star \star \star}$ & $(0.161)$ & $-0.644^{\star \star \star}$ & $(0.180)$ & $-0.777^{\star \star \star}$ & $(0.206)$ & $-0.755^{\star \star}$ & $(0.309)$ \\
\hline Age & -0.005 & $(0.006)$ & -0.006 & $(0.006)$ & -0.008 & $(0.006)$ & 0.006 & $(0.011)$ \\
\hline Unemployed & 0.022 & $(0.201)$ & 0.254 & $(0.224)$ & 0.350 & $(0.246)$ & 0.446 & $(0.389)$ \\
\hline Urban & -0.247 & $(0.168)$ & $-0.336^{\star}$ & $(0.187)$ & $-0.424^{\star \star}$ & $(0.205)$ & $-0.601^{\star}$ & $(0.337)$ \\
\hline $\begin{array}{l}\text { Central Region } \\
\text { (ref. Northern } \\
\text { Region) }\end{array}$ & 0.092 & $(0.217)$ & 0.237 & $(0.241)$ & 0.279 & $(0.274)$ & $0.956^{\star}$ & $(0.492)$ \\
\hline Coastal Region & -0.414 & $(0.265)$ & -0.277 & $(0.313)$ & -0.275 & $(0.352)$ & 0.429 & $(0.561)$ \\
\hline Constant & 0.520 & $(0.579)$ & 0.243 & $(0.614)$ & 0.731 & $(0.918)$ & -1.269 & $(1.866)$ \\
\hline Pseudo R2 & 0.27 & & 0.33 & & 0.34 & & 0.37 & \\
\hline Observations & 1,16 & & 1,0 & & 85 & & 40 & \\
\hline
\end{tabular}

Note: Robust standard errors in brackets. NS, SNS, and SRS not included because they perfectly predict lack of support for independence. Statistically significant coefficients at the 0.1 level in bold. ${ }^{* \star *} p<0.01,{ }^{\star \star} p<0.05,{ }^{\star} p<0.1$ 
Models 2 and 3 add political party preference and support for democratic principles, and Model 4 completes the specification with the addition of the variable gauging individual support for EU integration.

Model 1 confirms our basic expectations about the effect of identity on support for independence. Compared to the reference category, identification as Montenegrin, the probability of supporting independence decreases if the respondent identifies as Serb or claims dual identification as Montenegrin-Serb or Serb-Montenegrin. Albanian and Bosniak ethnic identifications, on the other hand, are associated with a higher likelihood of supporting independence compared to the baseline Montenegrin identification. Model 1 also incorporates socio-economic variables. Here we see that education is positively associated with the likelihood of supporting independence, although the association is only significant at the 0.1 level, and statistical significance disappears altogether when controlling for other variables in Models 2-4. Model 1 also confirms our expectations about the impact of income. Compared to the highest income category, lower and middle income categories are negatively associated with probability of supporting independence.

Model 2 incorporates partisanship. The new variables improve the model fit and we observe that sympathy for pro-independence parties is positively associated with support for independence. For example, DPS, LSCG, and DSA supporters are more likely to favor independence than respondents without party preference. Similarly, the likelihood of supporting independence is higher for the supporters of DSA, an ethnic Albanian party. The coefficient for SNP supporters, although negative, is not statistically significant. ${ }^{22}$ On the other hand, respondents who declared preference for Serb nationalist parties such as NS, SNS, and SRS were uniformly against the independence option and, because these variables perfectly predict lack of support for independence, they have to be excluded from the analysis. ${ }^{23}$

The results from Model 3 provide mixed evidence for the hypothesized association between support for democratic principles and preference for independence. We do not find a statistically significant relationship between support for an independent media and secessionist preference. However, we do find that support for minority rights, as measured by the belief that minorities should have the right to school in their own language, is positively associated with support for independence, all else equal.

The relationship between support for minority rights and preference for independence is particularly noteworthy when considering the majority population of Orthodox Slavs. While it is unsurprising that ethnic minorities would overwhelmingly support minority rights, we find relatively strong support for minority rights among self-identified Montenegrins as well: 70 percent of respondents who identified as Montenegrins supported the idea that minorities should have the right to schools in their own language; of these respondents, 56 percent supported independence and 43 percent opposed it. Among Serbs, 50 percent were favorable to the availability of education in minority languages. Overall, very few self-identified Serbs (12 respondents in total) supported independence, but 75 percent of those that did were also in favor of minorities having the right to schools in their own language. Needless to say, support for minority right to schools in their own language is an imperfect proxy for general support for minority rights. To account for this, we also investigated other variables that capture support for minority rights, specifically support for the right of minorities to have their own independent TV and news programs or support for minorities to have their own representatives in the legislature. The overall results were similar.

One of the advantages of quantitative analysis is that it enables us to estimate the relative effect size of different factors associated with support for independence. Calculating marginal effects, we find that, holding other variables in Model 3 at their means, compared to those who identify as Montenegrin, the probability of supporting independence decreases by 48 percent if the respondent identifies as Serb and by 31 percent if the respondent claims dual identification. On the other hand, all else equal, Albanians are 18 percent more likely than Montenegrins to favor independence whereas there is no statistically significant difference between Bosniaks and Montenegrins when it comes to supporting independence. Further, respondents in the lowest income category were 
16 percent less likely to support independence than respondents in the highest income category, whereas respondents in the middle income category were nine percent less likely to express support for independence compared to the baseline highest income category.

In terms of average marginal effects, DPS supporters were 34 percent more likely to favor independence than respondents without party preference, whereas LSCG supporters were 38 percent more likely to favor independence. The likelihood of supporting independence was even higher for supporters of the Albanian party, DSA. Its supporters were 56 percent more likely to favor independence than respondents without party sympathies. SNP supporters, on the other hand, were almost seven percent less likely to favor independence than respondents without party sympathies. We also find that those who support minority rights to attend school in their own language are nine percent more likely to favor independence than those who do not, ceteris paribus.

In addition, we have found that some control variables are also relevant in explaining attitudes towards independence. Sex and rural residence are negatively associated with support for independence, and the association is statistically significant. The probability of supporting independence is nine percent lower for a respondent living in an urban area compared to a similar respondent from a rural area, whereas women are 16 percent less likely than men to support independence. The other control variables in the model - age and unemployment status - do not display a statistically significant effect.

Finally, Model 4 tests the significance of attitudes towards EU integration. Note that the EU question was only included in one of the survey samples, which is why including this question in the model reduces the number of observations by more than half. Nonetheless, the results in Model 4 are important because they confirm the significance of attitudes towards EU integration. Holding other variables at their means, a one-unit increase in support for EU integration is associated with a 12 percent increase in the likelihood of supporting independence. To put this into context, someone who strongly supports EU integration is 60 percent more likely to support independence than someone who strongly opposes EU integration, all else equal. This indicates a strong and substantial association between attitudes towards joining the EU and secessionism in Montenegro.

Model 4 further confirms the importance of geographic region, as residence in the Central region of Montenegro is associated with a 20 percent higher likelihood of voting for independence compared to the Northern region. On the other hand, when controlling for all of the relevant variables, we do not find a statistically significant difference in secessionist preference between Coastal and Northern regions.

In order to verify the robustness of the results, we ran several alternative models, but the main results did not change. Among others, we obtained similar results when employing probit analysis or when we recoded variables measuring age and education. We also added additional variables that measure religiosity, self-placement in the left-right ideological scale, and ethno-nationalism, but the effect of these variables was not significant and including these variables in the models did not change the main results.

\section{Conclusion}

There are many factors at play in an individual's decision calculus of whether or not to support independence, be they cultural, socioeconomic, or political. Drawing from previous work on individual-level determinants of secession, this article considers which factors shaped support for independence in Montenegro. This article further substantiates previous claims that ethnic identity, education, income, partisanship, and attitudes towards EU integration affect support for independence among individuals. Montenegrin citizens who identify, even partially, as Serb are at a significantly lower likelihood of supporting independence than those who identify as Montenegrin, while identifying as a national minority, especially Albanian, increases such likelihood. When considering income, it is the low-income and middle-class Montenegrins who are less likely to support independence compared to the wealthiest Montenegrins. Supporters of DPS and LCSG, in 
addition to the ethnic Albanian party DSA, were much more likely to support independence, as were those who held a more favorable opinion of the EU.

This article makes important contributions in two areas of the literature: the study of Montenegro and the study of independence referenda as a whole. Regarding the former, first, to our knowledge this is the first article to systematically analyze several key factors affecting support for secession in Montenegro, contributing an important understanding to an understudied context and engaging in conversation with scholars of the case. Specifically, the use of comprehensive individual survey data that predates secession has allowed us to methodologically advance the quantitative study of Montenegrin independence. Past studies of public opinion in Montenegro, while immensely valuable, were primarily limited to descriptive statistics. Our analysis goes much further in systematically evaluating a broad set of theoretically and contextually relevant factors in attitudes towards independence. This enables us to be much more confident about our findings overall and more precise about the significance and size of the effect of individual factors accounting for preferences for independence.

Second, our finding that attitudes towards minority rights are associated with preference for independence is novel in the literature. Much of the literature on independence movements in the Balkans focuses on the importance of ethnic identity and interethnic relations in determining support for secession. Our findings call attention to a different factor: the impact of democratic governance. More specifically, our results indicate that, when considering whether or not to support secession, citizens may envision how the future policies implemented by both their current government and that of the newly independent entity will impact them, and how the outcome of the ensuing independence referendum will affect these policies. Accordingly, we offer the first quantitative evidence of the intrinsic importance to Montenegrins of membership in a state that protects minority groups.

We now turn to our contributions to the scholarship on independence referenda. First, we offer a fine-grained analysis of the impact of attitudes towards the EU on independence in a non-member state. Whereas previous work incorporated the EU into analysis of independence by considering the prospect of rejoining (Muro and Vasklamp 2016), individual survey responses that more directly capture opinion on European integration itself provide for interesting results in a state which had hopes of joining. Therefore, this result provides initial evidence that citizens, when considering the future of their state as a potentially independent entity, take into account not only sociotropic factors like ethnicity but also the ramifications of the actions of their new government.

Upon further examination of our chosen case of Montenegro, we identify several paths forward for scholars of independence attitudes. As discussed previously, minority rights and domestic governance decisions made by the central government should be considered when investigating why people support secession. Relatedly, corruption is often an issue in contentious political environments, and has a unique relationship to other governance factors such as the economy (Klašnja and Tucker 2013). How, then, might perceptions of corruption affect one's decision to support secession? Additionally, employment sector might have a significant impact on the decision to secede. Those whose jobs are closely tied to the central government may be less likely to support independence regardless of the presence of other factors that would predict it, as their economic security may be paramount to their ethnic identity. Indeed, just as the creation of a new sovereign state envelops all aspects of the sociopolitical sphere, the avenues for future research on the determinants of support for independence are many. Finally, it is important to investigate how attitudes towards independence change over time, and how these changes are shaped by and shape factors such as ethnic self-identification and party support.

Acknowledgements. We would like to thank the two anonymous reviewers for their valuable comments. We also thank Dr. Nataša Krivokapić of Univerzitet Crne Gore for her help in providing information about the South East European Social Survey Project.

Disclosures. None. 


\section{Notes}

1 Individual support for independence may also be important in shaping attitudes towards other policies and institutions, including, for example, attitudes towards peacekeeping missions in post-conflict societies (Kelmendi and Radin 2018).

2 The data applied in the analysis in this article are based on "South East European Social Survey Project - 2003-2004." The survey was financed by Research Council of Norway. The data are provided by Albert Simkus, and prepared and made available by NSD - Norwegian Centre for Research Data. Neither Albert Simkus, The Research Council of Norway nor NSD are responsible for the analyses/interpretation of the data presented here.

3 For detailed accounts of the history and politics of Montenegro in general and its road to independence in particular, see Bieber (2003) and Morrison (2017).

4 In the 1992 referendum, Montenegrins were asked to answer "yes" or "no" to the somewhat ambiguous question: "Do you agree that Montenegro, as a sovereign republic, should continue to exist in the joint country of Yugoslavia, on a completely equal basis with other republics who wish to do so?" (see Morrison 2017, 52).

5 Muñoz and Tormos $(2015,328)$ find that economic considerations of secession appear to matter more to those individuals in Catalonia with more ambivalent national identities.

6 One thorny methodological issue underlying some of these studies is the possibility of reverse causation, that is that preference for independence might in fact make people feel more or less attached to a particular identity.

7 As ICG $(2006,4)$ notes, it was not uncommon for members of the same family in Montenegro "to declare themselves differently, one as a Serb, another as a Montenegrin, a notable example being Montenegrin Foreign Minister Miodrag Vlahovic, whose brother declares himself as a Serb." This fluidity is also evident in the censuses collected in Montenegro: whereas in 1991 over 60 percent of the population declared themselves as Montenegrins and only 9.34 percent as Serbs, in the 2003 census the number of self-declared Montenegrins had dropped to 40.64 percent and the share of those who self-declared as Serbs had risen to 30.1 percent (Morrison 2009, 111-112).

8 By 2006 in Montenegro, according to ICG $(2006,4)$ "the way a person defines his or ethnic group seems to reflect largely that person's attitudes towards union with Serbia, Milosevic's policies, the vision of where Serbia's borders should lie, views of other national groups and war crimes about the Hague Tribunal."

9 Minorities were oversampled in the SEESSP survey to make it possible to make comparisons between ethnic groups. Estimations for country-wide population are made using a population weight (Simkus, 2007).

10 We code ethnic identity using the following survey question: "To which ethnic group or nationality do you mainly belong?" This question has been used in previous studies employing SEESP data such as Dyrstad (2012) and Ringdal and Simkus (2012). There were 32 possible answers. In addition to Montenegrin, Serb, Montenegrin-Serb, Serbian-Montenegrin, Albanian and Bosnian, other possible answers included Croat, Czech, Greek, Italian, Macedonian, Russian, Slovene, Yugoslav, Other, Mixed-can not describe, and Don't know. In the Montenegro survey, the response rate to this question was 94.6 percent. Note that although the Montenegro SEESSP survey coded all the Bosniak-Muslim minority respondents as Bosnian, in our discussion we use the term Bosniak. For a review concerning the debate over the appropriate appellation of Bosniak-Muslims in Montenegro, see Šistek and Dimitrovová (2003, 167-168).

11 We collapsed the "Montenegrin-Serb" and "Serbian-Montenegrin" categories, since they have low frequencies, 2.91 percent and 0.8 percent of the sample respectively.

12 This category includes Croats ( 1.37 percent), Macedonians ( 0.4 percent), Yugoslavs (0.4 percent), Slovenes ( 0.11 percent), and those who declared their ethnic group or nationality as Other (1.71 percent). 
13 Similarly, according to a UNDP survey conducted in July 2003, 14 percent of respondents refused to answer or did not have an opinion. Of those who did have an opinion, on the other hand, 52 percent supported a unified state whereas 48 percent supported two separate states (UNDP 2004, 18). A subsequent CEDEM survey conducted in May 2005 found that if a referendum were to be held the following year, 40.5 percent would vote in favor of Montenegro's independence, 36 percent would vote against, 10.1 percent would not participate at all, and 13.4 percent did not know (CEDEM 2006, 22).

14 We used the survey question "Apart from official party membership, which party do you like best now?" Possible responses included 14 major and minor political parties in Montenegro at the time, as well as "some other party" ( 0.8 percent) and "no party" ( 48.6 percent), which we use as the reference category. The response rate for this question was 86.6 percent.

15 The survey question used was "Do you 'agree strongly,' 'agree,' 'neither agree nor disagree,' 'disagree,' or 'strongly disagree,' with the statement ... This country should join the European Union." In the model, the responses to this question were reordered into an ordinal variable ranging from one for "strongly disagree," to five for "agree strongly." Those who refused to answer or stated that they do not know (5.2 percent of all the respondents) were treated as missing values and dropped from the analysis. Note that the SEESSP survey had a split sample design with two independent samples, referred to as samples "A" and "B." Most questions employed in this analysis were asked of all respondents in both samples, which allows for the analysis of the data in aggregated files. Some questions, however, were only asked in the A module or the B module (see Simkus 2007, 6). The EU question was only included in the B module, which is why including it in the model reduces the number of respondents by half.

16 The exact survey question used was the following: "Do you 'agree strongly,' 'agree,' 'neither agree nor disagree,' 'disagree,' or 'strongly disagree,' with the statement ... An independent media is necessary for the development of democracy." In the model, the responses to this question were reordered into an ordinal variable ranging from one for "strongly disagree," to five for "agree strongly."

17 We used the survey question "Now, for a moment, lets change to a few questions about what rights should be guaranteed for members of the minorities here in Montenegro, such as: Should minorities have the right to school in their own language?"

18 We used the survey question "All together, what is the total number of years of full time schooling you have had?"

19 We built four different dummy variables taking the value of 1 or 0 depending on whether the respondent belonged to one of the following four income categories: no income, low income, medium income, or high income.

20 We built three dummy variables for Montenegro's Northern, Central and Southern/coastal regions. Note that the regions of Montenegro are not administrative, and they were not defined as such until 2011. However, classification of Montenegrin regions for statistical analyses has a long history, based in part on the geographic socio-economic distinctions between the three regions (see Radović et al. 2006).

21 Scholars have also emphasized the role of tribal affiliation in determining political attitudes in Montenegro, including support for independence (see, for example, Calhoun 2000) although most scholars argue that the influence of tribal membership in politics is overstated (Bieber 2003, 41).

22 It is important to note that the vast majority of survey respondents who were SNP supporters (51 out of 55) were not in favor of independence.

23 Given the possibility of reverse causation, it is important to note that there is a need for further research on the relationship between party preference and attitudes towards independence.

\section{References}

Bieber, Florian. 2003. “Montenegrin Politics Since the Disintegration of Yugoslavia.” In Montenegro in Transition: Problems of Identity and Statehood, edited by Florian Bieber, 11-42. Baden-Baden: Nomos Verlagsgesellschaft. 
Bieber, Florian. 2013. “The Party System of Montenegro.” In Party Politics in the Western Balkans, edited by Věra Stojarová and Peter Emerson, 119-131. New York, NY: Routledge.

Blais, André, and Richard Nadeau. 1992. “To Be or Not to Be Sovereignist: Quebeckers' Perennial Dilemma.” Canadian Public Policy/Analyse de Politiques 18 (1): 89-103.

Calhoun, Steven C. 2000. “Montenegro's Tribal Legacy.” Military Review 80 (4): 32-40.

Caspersen, Nina, and Gareth R. Stansfield, eds. 2011. Unrecognized States in the International System. Cambridge: Routledge.

Centre for Democracy and Human Rights (CEDEM). 2006. Javno Mnjenje Crne Gore, Godišnjak br.2. Podgorica, Montenegro: Centar Za Demokratiju i Ljudska Prava.

Centre for Democracy and Human Rights (CEDEM). 2004. Političko Javno Mnjenje Crne Gore, April 2004. Podgorica, Montenegro: Centar Za Demokratiju i Ljudska Prava.

Clarke, Harold D., and Allan Kornberg. 1996. “Choosing Canada? The 1995 Quebec Sovereignty Referendum.” PS: Political Science \& Politics 29 (4): 676-682.

Clarke, Harold D., Allan Kornberg, and Marianne C. Stewart. 2004. "Referendum Voting as Political Choice: the Case of Quebec. British Journal of Political Science 34 (2): 345-355.

Coggins, Bridget. 2011. "Friends in High Places: International Politics and the Emergence of States from Secessionism." International Organization 65 (3): 433-467.

Costa Font, Joan, and Ramon Tremosa i Balcells. 2006. "National Identity and the Preference for State Opting-Out in the Basque Country.” Unversitat de Barcelona Facultat d’Economia i Empresa. Espai de Recerca en Economia Working Paper E06/151.

Cross, Sharyl, and Pauline Komnenich. 2005. "Ethnonational Identity, Security and the Implosion of Yugoslavia: The Case of Montenegro and the Relationship with Serbia." Nationalities Papers 33 (1): 1-27.

Darmanović, Srdjan. 2003. "Montenegro: The Dilemmas of a Small Republic." Journal of Democracy 14 (1): 145-153.

Dion, Stéphane. 1996. "Why is Secession Difficult in Well-Established Democracies? Lessons from Quebec." British Journal of Political Science 26 (2): 269-283.

Dyrstad, Karin. 2012. “After Ethnic Civil War: Ethno-Nationalism in the Western Balkans.” Journal of Peace Research 49 (6): 817-831.

Dyrstad, Karin. 2013. "Does Civil War Breed Authoritarian Values? An Empirical Study of Bosnia-Herzegovina, Kosovo and Croatia.” Democratization 20 (7): 1219-1242.

Džankić, Jelena. 2013. "Cutting the Mists of the Black Mountain: Cleavages in Montenegro's Divide over Statehood and Identity." Nationalities Papers 41(3): 412-430.

Džankić, Jelena. 2014. "Reconstructing the meaning of being 'Montenegrin." Slavic Review 73 (2): 347-371.

Eikemo, Terje Andreas, and Kristen Ringdal. 2016. "Health and Happiness in a European Comparison." In The Aftermath of War: Experiences and Social Attitudes in the Western Balkans, edited by Albert Simkus and Kristen Ringdal, 67-84. New York: Routledge.

Gehring, Kai and Stephan A. Schneider. 2020. “Regional Resources and Democratic Secessionism.” Journal of Public Economics 181: 1-18.

Hayes, Bernadette C., and Ian McAllister. 2001. "Sowing Dragon's Teeth: Public Support for Political Violence and Paramilitarism in Northern Ireland." Political Studies 49 (5): 901-922.

Horowitz, Donald L. 1981. "Patterns of Ethnic Separatism." Comparative Studies in Society and History 23 (2): 165-195.

Howe, Paul. 1998. "Rationality and Sovereignty Support in Quebec." Canadian Journal of Political Science 31(1): 31-59.

Huszka, Beata. 2003. "The Dispute Over Montenegrin Independence.” In Montenegro in Transition: Problems of Identity and Statehood, edited by Florian Bieber, 43-62. Baden-Baden: Nomos Verlagsgesellschaft.

Huszka, Beata. 2013. Secessionist Movements and Ethnic Conflict: Debate-Framing and Rhetoric in Independence Campaigns. New York: Routledge.

International Crisis Group (ICG). 2001. Montenegro: Settling for Independence? ICG Balkans Report No. 107.

International Crisis Group (ICG). 2006. Montenegro's Referendum. Crisis Group Europe Briefing No. 42.

Kim, Julie. 2006. Serbia and Montenegro Union: Background and Pending Dissolution. Congressional Research Service, Library of Congress.

Klašnja, Marko., and Joshua A. Tucker. 2013. “The economy, corruption, and the vote: Evidence from experiments in Sweden and Moldova." Electoral Studies 32 (3): 536-543.

Kelmendi, Pellumb, and Andrew Radin. 2018. "UNsatisfied? Public Support for Postconflict International Missions." Journal of Conflict Resolution 62 (5): 983-1011.

Liñeira, Robert, Ailsa Henderson, and Liam Delaney. 2017. "Voters' Response to the Campaign: Evidence from the Survey." In Debating Scotland: Issues of Independence and Union in the 2014 Referendum, edited by Michael Keating, 165-191. Oxford: Oxford University Press.

Macek-Macková, Emanuela. 2011. "Challenges in conflict management in multi-ethnic states-the dissolution of Czechoslovakia and Serbia and Montenegro.” Nationalities Papers 39 (4): 615-633.

Morrison, Kenneth. 2009. Montenegro: A Modern History. London: I. B. Taurus.

Morrison, Kenneth. 2017. Nationalism, Identity and Statehood in Post-Yugoslav Montenegro. London: Bloomsbury Academic.

Muñoz, Jordi, and Raül Tormos. 2015. "Economic expectations and support for secession in Catalonia: Between causality and rationalization.” European Political Science Review 7 (2): 315-341. 
Muro, Diego, and Martijn C. Vlaskamp. 2016. "How do prospects of EU membership influence support for secession? A survey experiment in Catalonia and Scotland.” West European Politics 39 (6): 1115-1138.

National Democratic Institute (NDI). 2004. Key Findings: Tracking Poll - May 2004. Montenegro: National Democratic Institute for International Affairs.

Nadeau, Richard, Pierre Martin, and André Blais. 1999. “Attitude Towards Risk-Taking and Individual Choice in the Quebec Referendum on Sovereignty.” British Journal of Political Science 29 (3): 523-539.

O'Gara, Matthew. 2001. "Inequality and political violence in a divided society: charismatic movements in Northern Ireland." Civil Wars 4: 79-98.

Pammett, John H., and Lawrence LeDuc. 2001. "Sovereignty, leadership and voting in the Quebec referendums." Electoral Studies 20 (2): 265-280.

Radović, Milivoje, Danijela Jaćimović, and Milorad Jovović. 2006. "Reaching balanced regional development in Montenegro: problems and solutions." SEER: Journal for Labour and Social Affairs in Eastern Europe 9 (4): 97-107.

Rastoder, Šerbo. 2003. “A Short Review of the History of Montenegro." In Montenegro in Transition: Problems of Identity and Statehood, edited by Florian Bieber, 107-138. Baden-Baden: Nomos Verlagsgesellschaft. .

Ringdal, Kristen, and Albert Simkus. 2012. The Aftermath of War. New York: Routledge.

Roeder, Philip G. 2018. National Secession: Persuasion and Violence in Independence Campaigns. Ithaca: Cornell University Press.

Sambanis, Nicholas, and Branko Milanovic. 2011. "Explaining the Demand for Sovereignty.” World Bank Policy Research Working Paper 5888.

Sarigil, Zeki and Ekrem Karakoç. 2016. "Who supports secession? The determinants of secessionist attitudes among Turkey's Kurds.” Nations and Nationalism 22 (2): 325-346.

Schumacher, Shannon. 2019. "Brexit Divides the UK, but Partisanship and Ideology Are Still Key Factors." http://www. pewresearch.org/fact-tank/2019/10/28/brexit-divides-the-uk-but-partisanship-and-ideology-are-still-key-factors/ (Accessed May 31, 2020.)

Serrano, Ivan. 2013. "Just a Matter of Identity? Support for Independence in Catalonia." Regional \& Federal Studies 23 (5): 523-545.

Simkus, Albert. 2007. “Guest Editor's Introduction: The SEESSP Project.” International Journal of Sociology 37 (3): 3-14.

Steenbergen, Marco R., Erica E. Edwards, and Catherine E. De Vries. 2007. "Who’s Cueing Whom? Mass-Elite Linkages and the Future of European Integration.” European Union Politics 8 (1): 13-35.

Šístek, František, and Bohana Dimitrovová. 2003. "National minorities in Montenegro after the Break-up of Yugoslavia." In Montenegro in Transition: Problems of Identity and Statehood, edited by Florian Bieber, 159-176. Baden-Baden: Nomos Verlagsgesellschaft.

Tesser, Lynn M. 2019. "Identity, Contingency, and Interaction: Historical Research and Social Science Analysis of Nation-State Proliferation.” Nationalities Papers 47 (3): 412-428.

Torcal, Mariano, and Fabiola Mota. 2014. "The role of political parties in shaping citizens' political preferences for the territorial organization of the state: The Spanish case." European Political Science Review 6 (3): 477-502.

United Nations Development Programme (UNDP). 2004. Aspiration Survey for Serbia and Montenegro. UNDP Regional Office Belgrade.

Wood, John R. 1981. “Secession: a Comparative Analytical Framework.” Canadian Journal of Political Science 14 (1): 107-34.

Cite this article: Kelmendi, P. and Pedraza, C. 2022. Determinants of Individual Support for Independence: Evidence from Montenegro. Nationalities Papers 50: 515-534, doi:10.1017/nps.2021.23 